\title{
Changes in Plasma Biochemistry and Body Mass During Incubation in the Yellow-legged Gull
}

Author(s): Carlos Alonso-Alvarez, Alberto Velando, Miguel Ferrer1, and José A. R. Veira

Source: Waterbirds, 25(2):253-258. 2002.

Published By: The Waterbird Society

DOI: http://dx.doi.org/10.1675/1524-4695(2002)025[0253:CIPBAB]2.0.CO;2

URL: http://www.bioone.org/doi/

full/10.1675/1524-4695\%282002\%29025\%5B0253\%3ACIPBAB\%5D2.0.CO

$\% 3 \mathrm{~B} 2$

BioOne (www.bioone.org) is a nonprofit, online aggregation of core research in the biological, ecological, and environmental sciences. BioOne provides a sustainable online platform for over 170 journals and books published by nonprofit societies, associations, museums, institutions, and presses.

Your use of this PDF, the BioOne Web site, and all posted and associated content indicates your acceptance of BioOne's Terms of Use, available at www.bioone.org/ page/terms_of_use.

Usage of BioOne content is strictly limited to personal, educational, and noncommercial use. Commercial inquiries or rights and permissions requests should be directed to the individual publisher as copyright holder. 


\title{
Changes in Plasma Biochemistry and Body Mass During Incubation in the Yellow-legged Gull
}

\author{
Carlos Alonso-Alvarez ${ }^{1,3}$, Alberto Velando ${ }^{2}$, Miguel Ferrer ${ }^{1}$ And José A. R. Veira $^{3}$ \\ ${ }^{1}$ Department of Applied Biology, Estación Biológica de Doñana, CSIC, 41013 Sevilla, Spain \\ E-mail: alonso@ebd.csic.es \\ ${ }^{2}$ Departamento de Ecoloxía e Bioloxía Animal, Universidade de Vigo, 36200 Vigo, Spain
}

${ }^{3}$ Departamento de Fisiología. Facultad de Veterinaria, Universidad de Santiago de Compostela. 27002 Lugo, Spain

\begin{abstract}
The "Incubatory Reserves Constancy" hypothesis asserts that incubation could be a departure from breeding stress that allows for the maintenance or recovery of body reserves after laying effort (females) or territory defense (males) in those species with bi-parental incubation such as gulls. The plasma composition and body mass of incubating Yellow-legged Gulls (Larus cachinnans) were analyzed and related to the number of days after egg-laying. Female gulls showed an increase in uric acid and cholesterol levels, whereas males showed only an increase in uric acid values throughout this period. Moreover, females increased while males maintained their body masses. These results could reflect a recovery process after the laying effort supporting the Incubatory Reserves Constancy hypothesis in females. Uric acid and urea levels are positively correlated to body condition in Yellow-legged Gulls, which could be the result of a change in diet composition. This disagrees with recent findings on body composition in incubating gulls and could be related to variations in food availability among populations or years, and could reflect flexibility in the investment devoted by each sex. Received 4 December 2001, accepted 18 February 2002.

Key words.-Body-mass change, Incubatory Reserves Constancy Hypothesis, Larus cachinnans, plasma cholesterol, uric acid, urea, Yellow-legged Gull, triglycerides.
\end{abstract}

Waterbirds 25(2): 253-258, 2002

Reproduction requires a high energetic expenditure in birds (Drent and Daan 1980; Blem 1990). The breeding effort commonly results in a decrease of lipid and protein reserves (e.g., Ankney and MacInnes 1978; Alisauskas and Ankney 1994). However, the incubation period could be an exception to this general pattern in those species with biparental care, since the energy expenditure would be distributed between both sexes (Moreno 1989). Thus two opposing hypotheses may be proposed for changes in the energy reserves during incubation: the "Stress Hypothesis" would predict a pattern of gradual loss of reserves, because energetic costs are accumulated throughout the breeding season (Monaghan et al. 1989; Wendeln and Becker 1996), whereas "Incubatory Reserves Constancy Hypothesis" would suggest that the incubation period may be a departure from breeding stress that allows for the maintenance or recovery of body reserves (see Houston et al. 1983; Hario et al. 1991; also suggested by Moreno [1989] for total body mass).

Gulls are monogamous species with bi-parental incubation (Cramp and Simmons
1983) and both sexes incubate for a similar proportion of time (Drent 1970; Burger 1987; Alonso-Alvarez 2001; but see Butler and Janes-Butler 1983). Hario et al. (1991) and Mawhinney et al. (1999) analyzed body composition of Herring Gulls (Larus argentatus) and Great Black-backed Gulls (Larus marinus) respectively, which were culled throughout the breeding season by governmental agencies to control their numbers. Hario et al. (1991) found that both sexes gained mass and fat during incubation, whereas protein reserves remained stable. In contrast, Mawhinney et al. (1999) found that mass and lipid content decreased and protein increased in females, while mass and protein remained stable and fat increased in males. Therefore, the results of these studies suggest different energy expenditure for each sex.

In the present study, we analyzed four plasma biochemical parameters (uric acid, urea, triglycerides and cholesterol) and body mass in incubating Yellow-legged Gulls (Larus cachinnans) to determine changes in reserves of living individuals, thus trying to avoid sacrifice of birds. Plasma levels of uric 
acid and urea reflect mobilization of protein reserves during food-shortage periods in birds (Cherel and Le Maho 1985; Boismenu et al. 1992; Alonso-Alvarez and Ferrer 2001). Plasma triglycerides value is related to body fat content (Bacon et al. 1989; Dabbert et al. 1997) and cholesterol level is a good indicator of body-mass loss from an individual's optimum in captive Yellow-legged Gulls (Alonso-Alvarez et al. 2002). However, few studies have analyzed changes in plasma chemistry throughout reproduction in freeliving birds (Fairbrother et al. 1990; Cantos et al. 1994; Hollmén et al. 2001). Moreover, as far as we know, the plasma chemistry of breeder individuals has not been previously analyzed in any gull species.

The objectives of the present study were: (1) to determine whether the incubation period represents maintenance or recovery after the pre-laying effort in Yellow-legged Gull, as the Incubatory Reserves Constancy Hypothesis suggests, (2) to evaluate between-sexes differences in the patterns of change in body mass and plasma chemistry, and whether they are consistent with the results provided by Hario et al. (1991) or Mawhinney et al. (1999), and finally, (3) to report gulls' plasma biochemistry during the breeding period.

\section{METHODS}

The study was carried out on the Cíes Islands $\left(42^{\circ} 15^{\prime} 04^{\prime \prime} \mathrm{N}, 8^{\circ} 53^{\prime} 30^{\prime \prime} \mathrm{W}\right)$, which are located in the outer area of the Ría de Vigo (Spain) and are the breeding grounds for over 22,000 pairs of Yellow-legged Gulls. Birds were captured using nest-traps (Weaver and Kadlec 1970) during the incubation period (May 1998). We trapped 33 males and 43 females throughout the 2731-d incubation period (Cramp and Simmons 1983). The beginning of incubation (following completion of clutch) was determined by visiting the colony every two $\mathrm{d}$. In the last $10 \mathrm{~d}$ of incubation, 13 females and four males that had been trapped on the first $10 \mathrm{~d}$ were recaptured.

We weighed the birds with a spring balance to the nearest $5 \mathrm{~g}$ (Pesola). Two milliliters of blood were taken from each bird with a heparinized syringe from the brachial vein. Blood samples were collected between 11.00 $\mathrm{h}$ and $18.00 \mathrm{~h}$ to minimize variations caused by circadian rhythms (see Ferrer 1990). The blood was placed in tubes containing lithium heparin, which were kept on ice in cool containers $\left(4^{\circ} \mathrm{C}\right)$ for a maximum period of eight $\mathrm{h}$. Then, samples were centrifuged at 3,000 rpm for $10 \mathrm{~min}$ and plasma stored at $-60^{\circ} \mathrm{C}$ until analysis.

Biochemical analyses were performed on a spectrophotometer (Hitachi-U2000, Tokyo, Japan). The deter- minations were made in duplicate on each plasma sample following the methods and authors indicated in parentheses: uric acid (uricase method; Fossati et al. 1980), urea (urease method; Munan et al. 1978), triglycerides (peroxidase-coupled method; McGowan et al. 1983), and cholesterol (cholesterol esterase method; Allain et al. 1974). These parameters were analyzed using commercial reagents (Sigma-Aldrich Company, MO, USA). All samples were assayed in the same series. Uric acid: intra-assay CV $=1.9 \%$, accuracy: $\pm 0.012 \mathrm{mmol} / \mathrm{L}$. Urea: intra-assay Coefficient of Variation $(\mathrm{CV})=1.54 \%$, accuracy: $\pm 0.33 \mathrm{mmol} / \mathrm{L}$. Triglycerides: intra-assay CV = $1.5 \%$; accuracy: $\pm 0.05 \mathrm{mmol} / \mathrm{L}$. Cholesterol: intra-assay $\mathrm{CV}=0.95 \%$, accuracy: $\pm 0.08 \mathrm{mmol} / \mathrm{L}$.

Data were tested for normality using the ShapiroWilk test. We used parametric tests because all variables were normally distributed. We tested between-sexes differences during first and last ten $\mathrm{d}$ of incubation by Student's t-test. Changes in plasma levels in the same individual between the first and the second sampling were tested by paired $t$-tests. Data of recaptured males were not used due to the small sample size. Relationships among variables were analyzed by Pearson correlation coefficients. In order to avoid pseudo-replication, recaptured males and females were not included in Pearson's correlations. An index of body condition (body mass corrected for size) was obtained as the residuals of the linear regression of body mass on cubed tarsus length of birds (males: $\mathrm{R}^{2}=0.18, \mathrm{~F}_{1,31}=6.74, \mathrm{P}<0.01$; females: $\left.\mathrm{R}^{2}=0.35, \mathrm{~F}_{1,41}=22.08, \mathrm{P}<0.001\right)$.

\section{RESULTS}

Female gulls showed lower urea and cholesterol concentrations than males during the first ten days of incubation (Table 1). There were no between-sexes differences in plasma levels during the middle ten days or during the last ten days of incubation (Table 1). Plasma concentration of uric acid in males $\left(\mathrm{t}_{21}=2.42, \mathrm{P}<0.05\right)$ and uric acid and cholesterol in females $\left(\mathrm{t}_{22}=3.13, \mathrm{P}<0.01 ; \mathrm{t}_{22}\right.$ $=2.93, \mathrm{P}<0.01$; respectively) showed significant increase between the first and the last 10-d periods (see Table 1). Moreover, the 13 females recaptured in the last days of incubation showed a significant increase in uric acid and cholesterol values (Table 2). Plasma variables and body condition index were not correlated with the laying date (n.s. in all cases and in both sexes).

In males, only uric acid showed a significant correlation with the number of days spent in incubation before blood extraction (Table 3). In females, uric acid, urea, cholesterol and body condition index were positively correlated with the day of incubation (Table 3). In addition, body mass was positively correlated with the day of incubation 


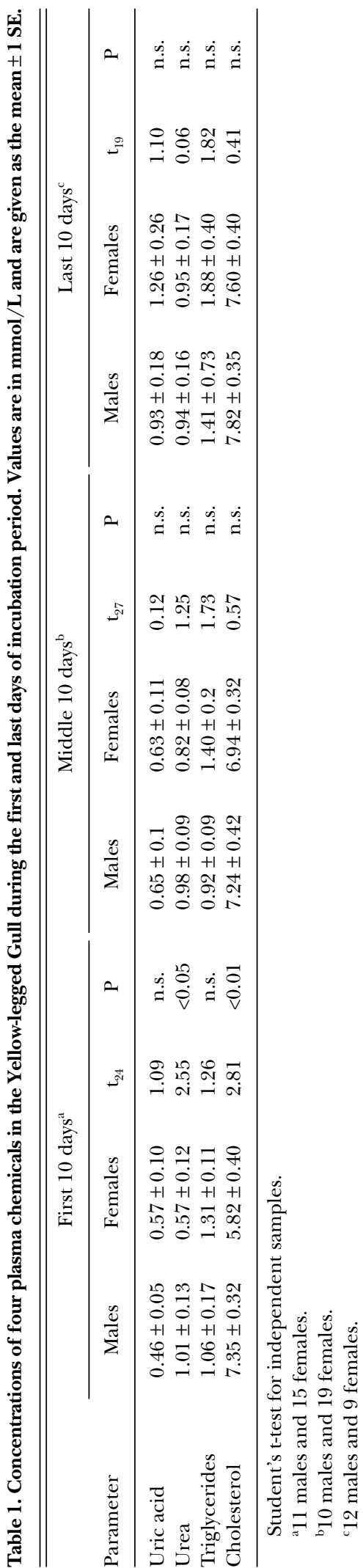

in females $\left(\mathrm{r}_{41}=0.33, \mathrm{P}<0.05\right)$, but not in males $\left(r_{31}=0.01\right.$, n.s. $)$. Finally, body condition index was positively correlated with uric acid $\left(\mathrm{r}_{41}=0.54, \mathrm{P}<0.001\right)$ and urea $\left(\mathrm{r}_{41}=\right.$ $0.37, \mathrm{P}<0.05)$ in females, and with uric acid in males $\left(\mathrm{r}_{31}=0.43, \mathrm{P}<0.05\right)$.

\section{DISCUSSION}

Breeding produces marked changes in the body mass of gulls (Coulson et al. 1983) and, as shown here, also in plasma composition during incubation. Body condition index, body mass and plasma biochemistry of Yellow-legged Gulls did not indicate a decrease in body reserves throughout this period. Hence, these results suggest that the "Stress Hypothesis" may be rejected in this species.

Nor do our findings support another hypothesis proposed to explain mass decrease during breeding, which is known as the "Programmed Anorexia Hypothesis" (Norberg 1981; Gaston and Jones 1989). It suggests that lipid storage levels may be minimized to maintain a low wing loading, thus increasing the flight efficiency. This would be an adaptive trait in seabirds since improves the foraging efficiency during the chick rearing period (i.e., Gaston and Jones 1989; Croll et al. 1991).

However, the results found in the present study may support the "Incubatory Reserves Constancy" hypothesis. Furthermore, male and female gulls differed in their patterns, such as Mawhinney et al. (1999) found. We detected an increase in body mass in females, but not in males during incubation. This might be related to between-sexes differences in energy expenditure before incubation, thus females recovering their previous state. In fact, females invest in egg production, which appreciably increases their energetic requirements. Unfortunately, we could not trap birds in the colony during the pre-laying period to test a recovery pattern. However, there were significant between-sexes differences in plasma composition during the first incubation days (see Table 1).

Plasma urea and uric acid are waste products of protein catabolism (Griminger and Scanes 1986). In birds, high levels have been associated with starvation and body mass 
Table 2. Values of four plasma chemicals (mmol/L) and body mass (g) of 13 female Yellow-legged Gulls captured in the first and last ten days of incubation. Values are given as mean $\pm 1 \mathrm{SE}$.

\begin{tabular}{lccccc}
\hline \hline & First 10 days & Last 10 days & Change & $\mathrm{t}_{12}$ & $\mathrm{P}$ \\
\hline Uric acid & $0.44 \pm 0.07$ & $0.68 \pm 0.09$ & $0.24 \pm 0.11$ & 2.15 & $<0.05$ \\
Urea & $0.63 \pm 0.09$ & $0.89 \pm 0.13$ & $0.26 \pm 0.14$ & 1.86 & n.s. \\
Triglycerides & $1.25 \pm 0.13$ & $1.16 \pm 0.14$ & $-0.09 \pm 0.12$ & 0.74 & n.s. \\
Cholesterol & $6.35 \pm 0.49$ & $7.69 \pm 0.27$ & $1.34 \pm 0.55$ & 2.44 & $<0.05$ \\
Body mass & $775 \pm 18.9$ & $784 \pm 20.8$ & $9.17 \pm 23.08$ & 0.40 & n.s. \\
\hline
\end{tabular}

Student's t-paired test.

loss, because muscular protein is used as energy source during the last phase of fasting (Cherel and Le Maho 1985; Boismenu et al. 1992; Castellini and Rea 1992). In the same way, plasma urea has been used as a nutritional condition index (Ferrer 1992, 1993). The protein is a limiting factor during albumen production among bird species (Williams 1996; Ramsay and Houston 1997), including gulls (Herring Gull; Houston et al. 1983). As female gulls differentially suffered the costs of egg production, we should expect high nitrogen values at the start of incubation, decreasing throughout this period. Surprisingly, we found the opposite.

In a recent study, Hollmén et al. (2001) found an increase of uric acid plasma levels in female Common Eiders (Somateria mollissi$m a$ ) during incubation. The Common Eider has uni-parental incubation. Female Eiders rarely leave their nest to feed during this period $(26 \mathrm{~d})$, relying energetically on their body reserves to lost approximately $30 \%$ of their body masses (Parker and Holm 1990). Hollmén et al. (2001) related the uric acid increase to mobilization of protein reserves

Table 3. Pearson correlation between the day of incubation and four plasma parameters and residuals of body mass on body size (body condition).

\begin{tabular}{lcccccc}
\hline & \multicolumn{2}{c}{ Males $^{\mathrm{a}}$} & & \multicolumn{2}{c}{ Females $^{\mathrm{b}}$} \\
\cline { 2 - 3 } \cline { 5 - 6 } Parameter & $\mathrm{r}_{31}$ & $\mathrm{P}$ & & $\mathrm{r}_{41}$ & $\mathrm{P}$ \\
\hline Uric acid & 0.341 & $<0.05$ & & 0.538 & $<0.001$ \\
Urea & -0.061 & n.s. & & 0.322 & $<0.05$ \\
Triglycerides & 0.238 & n.s. & & 0.228 & n.s. \\
Cholesterol & 0.229 & n.s. & & 0.399 & $<0.01$ \\
Body condition & 0.099 & n.s. & & 0.389 & $<0.05$ \\
\hline
\end{tabular}

${ }^{\mathrm{a}} \mathrm{N}=33$.

${ }^{\mathrm{b}} \mathrm{N}=43$. and body-mass loss. However, our results suggest that in other circumstances this relationship may be reversed. Both urea and uric acid were positively correlated with body mass corrected for body size in Yellow-legged Gull. Hence, such relationships must be carefully considered. A possible explanation might derive from changes in diet.

A rise in the proportion of protein in the diet increased the plasma level of these nitrogen metabolites in chickens and pigeons (Okumura and Tasaki 1969; Featherston 1969; Lumeij and Bruijne 1985). Therefore, our results relate to diet differences, allowing female gulls to increase their protein reserves. The studied birds often fed on refuse tips (rubbish present in the $40 \%$ of pellets [Munilla 1997a]), and showed marked modifications in diet throughout the breeding period, as the occurrence of crabs in regurgitations increases significantly during incubation (Munilla 1997b). An increase in the proportion of crustaceans has also found in the diet of Kelp Gulls (Larus dominicanus) in the same period (Bertellotti and Yorio 1999).

On the other hand, triglyceride values did not change during incubation in either sex, indicating stable lipid reserves, since the amount of body fat is positively correlated with plasma triglycerides values (Bacon et al. 1989; Dabbert et al. 1997). Furthermore, cholesterol is lower in females during the first ten days, increasing during the rest of incubation period. In Yellow-legged Gulls, the plasma concentration of this lipid is negatively correlated with the individual proportion of body-mass loss, thus providing a reliable index of the body condition (Alonso-Alvarez et al. 2002). Incubating gulls with high cholesterol levels would be relatively heavy birds. 
The cholesterol increase bears out the presence of a recovery pattern in female birds.

In summary, the present results support the hypothesis that body mass and reserves maintain or recover their levels during incubation in those species with bi-parental care. However, whereas females increased body mass, and probably changed diet composition in order to recuperate the protein expenditure during laying effort, males maintained body mass, lipids and protein metabolites throughout incubation. These results are not consistent with the results of Hario et al. (1991) on Herring Gulls or Mawhinney et al. (1999) on Great Blackbacked Gulls. The differences between the two studies were explained by differences in the energy expenditure of the sexes during incubation (Mawhinney et al. 1999). Female Great Black-backed Gulls spent more time on the nest than males, thus reducing her feeding time (Butler and Janes-Butler 1983). Alternatively, the disagreement between Hario et al. (1991), Mawhinney et al. (1999) and the present paper might be related to differences in food availability (Kitaysky et al. 1999). Differences in food abundance produced a readjustment of each sex role during incubation in Western Gulls (Larus occidentalis; Pierotti 1981). The plasma chemistry during the incubation period should be analyzed under different food-availability situations, which could be easily manipulated by means of an artificial food supply. Moreover, the relationship between food composition and plasma biochemistry in wild birds should be examined.

\section{ACKNOWLEDGMENTS}

We are grateful to the staff of Islas Cíes Natural Park. We thank to J. L. Tella, Bertellotti, M. and V. Penteriani for their valuable comments. The capture and sampling of birds were conducted under legal permission from the wildlife authorities (Xunta de Galicia), avoiding unnecessary damages to the birds.

\section{LiTERATURE CITED}

Alisaukas, R. T. and C. D. Ankney. 1994. Nutrition of breeding female Ruddy Ducks: the role of nutrient reserves. Condor 96: 878-897.

Allain, C. A., L. S. Poon, C. S. G. Chan, W. Richmond and P. C. Fu. 1974. Enzymatic determination of total serum cholesterol. Clinical Chemistry 20: 470-478.
Alonso-Alvarez, C. 2001. Effects of testosterone implants on pair behaviour during incubation in the Yellowlegged Gull Larus cachinnans. Journal of Avian Biology 32: 326-332.

Alonso-Alvarez, C. and M. Ferrer. 2001. Biochemical study about fasting, subfeeding and recovery processes in Yellow-legged Gulls. Physiological and Biochemical Zoology 74: 703-713.

Alonso-Alvarez, C., M. Ferrer and A. Velando. 2002. The plasmatic index of body condition in Yellow-legged Gulls (Larus cachinnans): a food-controlled experiment. Ibis 144: 147-150.

Ankney, C. D. and C. D. MacInnes. 1978. Nutrient reserves and reproductive performance of female Lesser Snow Geese. Auk 95: 459-471.

Bacon, W. L., K. E. Nestor and E. C. Naber. 1989. Prediction of carcass composition of turkeys by blood lipids. Poultry Science 68: 1282-1288.

Bertellotti, M. and P. Yorio. 1999. Spatial and temporal patterns in the diet of the Kelp Gull in Patagonia. Condor 101: 790-798.

Blem, C. R. 1990. Avian energy storage. Pages 59-113 in Current Ornithology, Vol. 7 (D. M. Power, Ed.). Plenum Press, New York.

Boismenu, C., G. Gauthier and J. Larrochelle. 1992. Physiology of prolonged fasting in Greater Snow Geese (Chen caerulescens atlantica). Auk 109: 511-521.

Burger, J. 1987. Selection for equitability in some aspects of reproductive investment in Herring Gulls Larus argentatus. Ornis Scandinavica 18: 17-23.

Butler, R. G. and S. Janes-Butler. 1983. Sexual differences in the behaviour of the adult Great Black-backed Gulls (Larus marinus) during the pre-and-post hatch periods. Auk 100: 63-75.

Cantos, F. J., A. L. Alonso-Gómez and M. J. Delgado. 1994. Seasonal changes in fat and protein reserves of the Black-headed Gull, Larus ridibundus, in relation to migration. Comparative Biochemistry and Physiology 108A: 117-122.

Castellini, M. A. and L. D. Rea. 1992. The biochemistry of natural fasting at its limits. Experientia 48: 575-582.

Cherel, Y. and Y. Le Maho. 1985. Five months of fasting in King Penguin chicks: body mass loss and fuel metabolism. American Journal of Physiology 249: R387-392.

Coulson, J. C., P. Monaghan, J. Butterfield, N. Duncan, C. Thomas and C. Shedden. 1983. Seasonal changes in the Herring Gull in Britain: weight, moult and mortality. Ardea 71: 235-244.

Cramp, S. and K. E. L. Simmons. 1983. Handbook of the birds of Europe, The Middle East and North Africa. The birds of Western Paleartic. Vol. III. Waders to Gulls. Oxford University Press, Oxford.

Croll, D. A., A. J. Gaston and D. G. Noble. 1991. Adaptive loss of mass in thick-billed murres. Condor 93: 496-502.

Dabbert, C. B., T. E. Martin and K. C. Powell. 1997. Use of body measurements and serum metabolites to estimate the nutritional status of Mallards wintering in the Mississippi Alluvial Valley, USA. Journal of Wildlife Diseases 33: 57-63.

Drent, R. H. 1970. Functional aspects of incubation in the Herring Gull (Larus argentatus). Behaviour 17: S1-S132.

Drent, R. H. and S. Daan. 1980. The prudent parent: energetic adjustments in avian breeding. Ardea 68: 225-252.

Fairbrother, A., M. A. Craig, K. Walker and D. O'Loghlin. 1990. Changes in Mallard (Anas platyrhynchos) serum chemistry due to age, sex and reproductive condition. Journal of Wildlife Diseases 26: 67-77. 
Featherston, W. R. 1969. Nitrogenous metabolites in the plasma of chicks adapted to high protein diets. Poultry Science 48: 646-651.

Ferrer, M. 1990. Hematological studies in birds. Condor 92: 1085-1086.

Ferrer, M. 1992. Natal dispersal in relation to nutritional condition in Spanish Imperial Eagles. Ornis Scandinavica 23: 104-107.

Ferrer, M. 1993. Ontogeny of dispersal distances in young Spanish Imperial Eagles. Behavioral Ecology and Sociobiology 32: 259-263.

Fossati, P., L. Prencipe and G. Berti. 1980. Use of 3,5dichloro-2-hydroxybenzene-sulfonic acid/4-aminophenazone chromogenic system in direct enzymatic assay of uric acid in serum and urine. Clinical Chemistry 26: 227-231.

Gaston, A. J. and I. L. Jones. 1989. The relative importance of stress and programmed anorexia in determining mass loss by incubating ancient murrelets. Auk 106: 653-658.

Griminger, P. and C. G. Scanes. 1986. Protein metabolism. Pages 326-344 in Avian Physiology (P. D. Sturkie, Ed.). Springer-Verlag, New York.

Hario, M., M. Kilpi and K. Selin. 1991. Parental investment by sexes in Herring Gull: the use of energy reserves during the early season. Ornis Scandinavica 22: 308-312.

Hollmén, T., J. C. Franson, S. Sankari, M. Kilpi and K. Lindström. 2001. Use of serum biochemistry to evaluate nutritional status and health of incubating Common Eiders (Somateria mollisima) in Finland. Physiological and Biochemical Zoology 74: 333-342.

Houston, D. C., P. J. Jones and R. M. Sibly. 1983. The effect of female body condition on egg laying in Lesser Black-backed Gulls Larus fuscus. Journal of Zoology, London 200: 509-520.

Kitaysky, A. S., J. C. Wingfield and J. F. Piatt. 1999. Dynamics of food availability, body condition and physiological stress in breeding Black-legged Kittiwakes. Functional Ecology 13: 577-584.

Lumeij, J. T. and J. J. Bruijne. 1985. Blood chemistry reference values in Racing Pigeons (Columba livia domestica). Avian Pathology 14: 401-408.

Mawhinney, K., A. W. Diamond and F. P. Kehoe. 1999. The use of energy, fat, and protein reserves by breeding Great Black-backed Gulls. Canadian Journal of Zoology 77: 1459-1464.

McGowan, M. W., J. D. Artiss, D. R. Strandberg and B. Zak. 1983. A peroxidase-coupled method for the col- orimetric determination of serum triglycerides. Clinical Chemistry 29: 538-542.

Monaghan, P., J. D. Uttley, M. D. Burns, C. Thaine and J. Blackwood. 1989. The relationship between the food supply, reproductive effort and breeding success in Arctic Terns Sterna paradisaea. Journal of Animal Ecology 58: 261-274.

Moreno, J. 1989. Strategies of mass change in breeding birds. Biological Journal of the Linnean Society 37 : 297-310

Munan, L., A. Kelly, C. PetitClerc and B. Billon. 1978. Associations with body weight of selected chemical constituents in blood: epidemiologic data. Clinical Chemistry 24: 772-777.

Munilla, I. 1997a. Estudio de la Población y la Ecología Trófica de la Gaviota Patiamarilla, Larus cachinnans Pallas, en Galicia. Unpublished Ph.D. Thesis. University of Santiago de Compostela, Santiago de Compostela.

Munilla, I. 1997b. Henslow's Swimming Crab (Polybius henslowii) as an important food for Yellow-legged Gulls (Larus cachinnans) in NW Spain. I.C.E.S. Journal of Marine Sciences 54: 631-634.

Norberg, R. A. 1981. Temporary weight decrease in breeding birds may result in more fledged young. American Naturalist 118: 838-850.

Okumura, J. and I. Tasaki. 1969. Effect of fasting, refeeding and dietary protein level on uric acid and ammonia content of blood, liver and kidney in chickens. Journal of Nutrition 97: 316-320.

Parker, H. and H. Holm. 1990. Patterns of nutrient and energy expenditure in female Common Eiders nesting in the high Arctic. Auk 107: 660-668.

Pierotti, R. 1981. Male and female parental roles in the Western Gull under different environment conditions. Auk 98: 532-549.

Ramsay, S. L. and D. C. Houston. 1997. Nutritional constraints on egg production in the Blue Tit: a supplementary feeding study. Journal of Animal Ecology 66: 649-657.

Weaver, D. K. and J. A. Kadlec. 1970. A method for trapping breeding adult gulls. Bird-Banding 41: 28-31.

Wendeln, H. and P. H. Becker. 1996. Body mass change in breeding Common Terns Sterna hirundo. Bird Study 43: 85-95.

Williams, T. D. 1996. Variation in reproductive effort in female Zebra Finches (Taeniopygia guttata) in relation to nutrient-specific dietary supplements during egg laying. Physiological Zoology 69: 1255-1275. 